\title{
A review on alcohol: from the central action mechanism to chemical dependency
}

João Victor Vezali Costardi ${ }^{1}$, Rafael Augusto Teruakı Nampo ${ }^{1}$, Gabriella Lourenço Silva ${ }^{1}$, Maria Aparecida Ferreira Ribeiro², Heryck José Stella ${ }^{3}$, Mercia Breda Stella ${ }^{4}$, Sônia Valéria Pinheiro Malheiros ${ }^{5 *}$

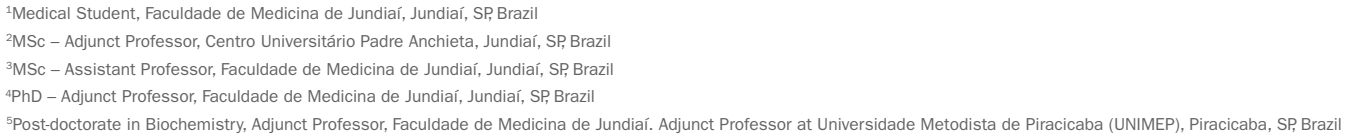

Study conducted at the Faculdade de Medicina de Jundiaí, Jundiaí, SP, Brazil

Article received: 9/19/2014 Accepted for publication: 10/22/2014

*Correspondence: Address: Rua Francisco Telles, 250 Vila Arens

Jundiaí, SP - Brazil

Mail Box 1295 Postal code: 13202-505

+55 11 4587-1095 sonia.malheiros@uol.com.br

http://dx.doi.org/10.1590/1806-9282.61.04.381

\section{SUMmARY}

Introduction: alcohol is a psychotropic depressant of the central nervous system (CNS) that promotes simultaneous changes in several neuronal pathways, exerting a profound neurological impact that leads to various behavioral and biological alterations.

Objectives: to describe the effects of alcohol on the CNS, identifying the signaling pathways that are modified and the biological effects resulting from its consumption.

Methods: a literature review was conducted and articles published in different languages over the last 15 years were retrieved.

Results: the studies reviewed describe the direct effect of alcohol on several neurotransmitter receptors (gamma-aminobutyric acid [GABA], glutamate, endocannabinoids AEA and 2-AG, among others), the indirect effect of alcohol on the limbic and opioid systems, and the effect on calcium and potassium channels and on proteins regulated by GABA in the hippocampus.

Discussion and conclusion: the multiple actions of alcohol on the CNS result in a general effect of psychomotor depression, difficulties in information storage and logical reasoning and motor incoordination, in addition to stimulating the reward system, a fact that may explain the development of addiction. Knowledge on the neuronal signaling pathways that are altered by alcohol allows the identification of effectors which could reduce its central action, thus, offering new therapeutic perspectives for the rehabilitation of alcohol addicts.

Keywords: alcohol-induced disorders, nervous system, neurotransmitter receptors.

\section{INTRODUCTION}

The alcohol found in beverages such as wine and beer is chemically classified as ethanol. Ethanol consists of a chain of two carbons and a hydroxyl group (-OH). These characteristics confer a perfect hydrophilic-hydrophobic balance which, together with the low weight of the molecule, ${ }^{1}$ guarantees an immense capacity for diffusion and distribution in all body fluids and tissues, favoring its partitioning in the central nervous system (CNS). ${ }^{2}$

The effects of alcohol on the individual and its capacity to alter behavior have been known since the beginning of its consumption by different societies. Although alcohol is not classically viewed as a drug in Brazil, it is considered as a psychotropic CNS depressant and its consumption is one of the highest among all psychoactive substances, a fact that has numerous consequences.

The objective of this study was to perform an extensive, but not necessarily comprehensive, literature review of the effects of alcohol on the CNS, describing the neuronal changes induced by alcohol, as well as biological and behavioral effects that can explain the development of chemical dependency and contribute to the elaboration of new therapeutic measures. 


\section{Methods}

For this study, books and articles published in printed and electronic journals of the PubMed, Medline and Scielo databases were searched, using the following Health Sciences Descriptors (DeCS) and Medical Subject Headings (MeSH): alcohol, receptor, and central action.

A total of 159 studies on the effect of alcohol on the CNS were reviewed and 62 were selected, with priority being given to articles published over the last 15 years. Articles investigating the systemic actions of alcohol in the organism, articles describing only alcohol-induced genetic and structural modifications in receptors, and articles not reporting interactions with specific receptors or the biological effects induced by the interaction of alcohol with the CNS were excluded.

\section{RESULTS}

\section{Effects of alcohol on gabaminergic and glutamatergic} transmission

Alcohol is a psychotropic depressant of the CNS. ${ }^{3,4}$ This property is associated with the action of alcohol on different neurotransmitters, including the stimulation of gamma-aminobutyric acid (GABA), the main inhibitory neurotransmitter of the CNS, and the inhibition of glutamate, the main central excitatory neurotransmitter. Alcohol potentiates the effects of GABA by acting directly on its receptors, enhancing their inhibitory effects. ${ }^{5}$ These inhibitory effects include sedation, loss of inhibitions and relaxation, and might be related to the production of certain neurosteroids, such as allopregnanolone. The latter may be a mediator of these effects in the brain, since neuroactive steroids are positive allosteric modulators of neurotransmitter receptors, such as $\mathrm{GABA}_{\mathrm{A}}$.

The $\mathrm{GABA}_{\mathrm{A}}$ receptor-ionophore complex is widely distributed throughout the CNS and its activation causes opening of chloride channels, with consequent hyperpolarization of the membrane and production of a postsynaptic inhibitory potential. ${ }^{6}$ This receptor consists of various classes of subunits (a, b, g, d, and r) that confer different pharmacological properties. ${ }^{7-9}$ In studies on ethanol-dependent animals, messenger RNA (mRNA) levels of the a1 and a2 subunits of the $\mathrm{GABA}_{\mathrm{A}}$ receptor were found to be significantly reduced, whereas a significant increase was observed in mRNA levels of the a4, g1 and g2S subunits. ${ }^{10}$ In contrast, conflicting results have been reported in other studies also using chemically dependent animals, i.e., low levels of a 4 peptides and no difference in the levels of subunit g2. ${ }^{10,11}$ These results suggest that changes in the expression of $\mathrm{GABA}_{\mathrm{A}}$ receptor subunit genes lead to populations of receptors with properties that differ from the non-ethanol-dependent state. ${ }^{10}$ In this respect, molecular biology studies using Xenopus laevis oocytes indicate that ethanol only potentiates receptors that contain the long variant of the g2 subunit. Since only the long, but not the short, subunit possesses a phosphorylation site, it is possible that the phosphorylation state is important for the inhibitory effect of ethanol. ${ }^{12}$

In the case of long-term alcohol use, GABA receptor down-regulation reduces the number of receptors, an event that would explain the effect of alcohol tolerance, i.e., the fact that individuals require higher doses of alcohol to achieve the same symptoms of inhibition as obtained previously with lower doses. ${ }^{13,14}$ The loss of inhibitory effects and GABA receptor deficiency result in withdrawal symptoms. $^{6}$

Studies also indicate that the long-term use of alcohol causes detectable memory impairments, mainly by reducing hippocampal mass mediated by GABA. ${ }^{13}$ The hippocampus is related to explicit memories, i.e., memories we can talk about, such as last night's dinner or the date of a historical event. Explicit memory involves the conscious recollection of information. The hippocampus is known to be necessary for the acquisition of this type of memory, since damage to this region prevents individuals from establishing new explicit memories. ${ }^{15}$ However, it is possible to recover older explicit memories that were stored before the damage had occurred. A key element in these events is a signal transduction pathway mediated by Mitogen-Activated Protein Kinases (MAPK). MAPKs are important, signaling proteins that are activated by neurotransmitters and different growth factors. One member of this family is extracellular signal-regulated kinase (ERK). The ERK cascade is used in all brain regions where synaptic plasticity occurs and its activation is needed for the formation of new memories. If ERK activity is blocked by the injection of an inhibitor into a certain brain region, such as the amygdala, the formation of all modes of learning associated with this structure will be blocked. Similarly, the blockade of ERK activity in the hippocampus prevents the hippocampal formation of explicit memories. Excessive alcohol consumption suppresses the phosphorylation of these protein kinases (ERK), ${ }^{15}$ which is regulated by GABA. ${ }^{16}$ Thus, ethanol abuse prevents activation of the memory circuit, in this case, the explicit memory supported by the hippocampus. ${ }^{14}$

In the case of glutamate, the loss of ionotropic (AMPA, kainate or NMDA) and metabotropic receptors (rM1, rM8) leads to a reduction in excitatory glutamatergic neurotransmission. ${ }^{17}$ The activation of ionotropic receptors increases intracellular calcium $\left(\mathrm{Ca}^{2}\right)$ through different routes, 
such as influx through ionotropic receptor channels, influx through voltage-sensitive calcium channels which are activated by membrane depolarization, and the release of $\mathrm{Ca}^{2}$ from endoplasmic reticulum stores. The last mechanism is controlled by the ryanodine receptor, which is activated by intracellular $\mathrm{Ca}^{2}$ concentrations. ${ }^{18}$ This increase in intracellular $\mathrm{Ca}^{2}$ can lead to attention deficits and impaired sleep-wake regulation in the locus coeruleus and even to the blackout phenomenon in the hippocampus. ${ }^{19}$ Recent studies have shown that $\mathrm{Ca}^{2}$ increases, mediated by the activation of AMPA/kainate receptors, metabotropic receptors and $\mathrm{K}$ depolarization, are altered by the acute administration of ethanol to cultured cerebellar Purkinje neurons, which are known to possess abundant $\mathrm{Ca}^{2}$ channels. ${ }^{3}$ In this respect, it was demonstrated that the administration of an AMPA receptor agonist increases $\mathrm{Ca}^{2}$ concentrations in the somatic and dendritic regions of Purkinje neurons; however, ethanol altered this response in a dose-dependent manner. No effect was observed at a dose of $10 \mathrm{mM}$, whereas doses of 33 and 66 $\mathrm{mM}$ caused a significant reduction. Similarly, metabotropic receptor agonists also increased $\mathrm{Ca}^{2}$-concentrations in the two regions of Purkinje neurons. However, these signals were enhanced by the administration of $10 \mathrm{mM}$ ethanol, but not of 33 or $66 \mathrm{mM}$. The results of that study suggest that the components of the $\mathrm{Ca}^{2}$-signaling pathway that are sensitive to ethanol are located in Purkinje neurons. Ethanol exerts a maximum effect on AMPA receptors at a dose of $33 \mathrm{mM}$ and the activation of metabotropic receptors is highly sensitive to the acute effect of ethanol. However, ethanol sensitivity related to glutamatergic transmission probably depends on the glutamate receptor subtype, since the $\mathrm{Ca}^{2}$ signals related to the activation of ionotropic and metabotropic receptors vary in sensitivity and in the response to ethanol. ${ }^{18}$ On the other hand, the NMDA receptor is the main receptor involved in neuronal death due to increased permeability of the $\mathrm{Ca}^{2}$ channel associated with this receptor. ${ }^{20-22}$ This receptor has been suggested to play an important role in the neurotoxicity observed in alcohol abuse and in alcohol withdrawal syndrome. This neurotoxicity is related to a decrease in mitochondrial membrane potential and in $\mathrm{Na}$ /K ATPase and Mg2 -ATPase activity. ${ }^{12,23,24}$

In contrast, the long-term use of alcohol leads to an increase in glutamatergic receptors in the hippocampus, an area that is important for memory and that is involved in seizures. ${ }^{5}$ As a consequence, during alcohol withdrawal the glutamate receptors that were accustomed to the continuous presence of alcohol become hyperactive and can trigger seizures or even strokes. ${ }^{25}$

\section{Effects of alcohol on opioid and dopaminergic transmission} Alcohol also exerts effects on the reward system through the opioid and dopaminergic systems. ${ }^{26}$ This effect is mediated by the release of dopamine in the ventral tegmental area and in the nucleus accumbens of the limbic system. ${ }^{19,27-29} \mathrm{~A}$ large number of natural opioid receptors are found around these areas. There are three classes of opioid receptors involved in opioid dependence: mu, delta and kappa. ${ }^{26,29}$ Opioids activate the reward system in an indirect manner through two actions. The first consists of the binding of opioids to opioid receptors within the reward system..$^{27,29}$ This binding triggers a signal to release the neurotransmitter dopamine into the synaptic cleft where it binds to D-1 and D-2 receptors of the nerve cell, activating the reward system in the CNS. ${ }^{19,29,30}$ The second action would be through the GABA system, which inhibits the release of dopamine. However, opioids block the action of this system. As a consequence, the effects of dopamine become more potent and long lasting. ${ }^{31}$ Within this context, alcohol acts directly on these opioid receptors, with the description of a positive effect on mu opioid receptors, which is related to the feeling of pleasure and stimulation of dopamine release, and a negative effect on delta receptors, increasing alcohol addiction. Studies also report that alcohol can increase the number of beta opioid receptors, which stimulate the release of dopamine. Therefore, the opioid system acts directly on the reward system and is associated with the development of addiction. ${ }^{29}$

\section{Effects of alcohol on serotoninergic transmission}

Serotonin (5-HT) and endorphins seem to contribute to the symptoms of well-being and mood elevation observed in alcohol intoxication. ${ }^{25,32-34}$ Many studies have analyzed the effects of alcohol on serotonin neurotransmission in the brain. These studies showed that serotonin transmission is increased after the acute administration of alcohol and reduced during alcohol withdrawal. ${ }^{33,35}$ Reduced neurotransmission of serotonin in dependent animals might be associated with relapse. For example, when serotonin neurotransmission was inhibited by the injection of a GA$\mathrm{BA}_{\mathrm{A}}$ receptor agonist into the brainstem (which reduces serotonin activity), the consumption of alcohol by the animals was lower. ${ }^{36}$ There are several serotonin receptor subtypes $^{37}$ and serotonin may affect alcohol consumption by the activation of specific receptors. ${ }^{32,33}$ In this respect, activation of 5-HT2C or 5-HT1A receptors has been shown to reduce alcohol consumption. ${ }^{32,33,38,39}$ However, controversy exists in the literature, showing that both an increase and a decrease in 5-HT1B receptor production can in- 
crease ethanol consumption. ${ }^{32,33,40-42}$ The overproduction of the 5-HT1B receptor is supposed to produce more significant changes. On the other hand, inhibition of the 5-HT3 receptor has been shown to substantially reduce alcohol consumption. ${ }^{43}$

The effects of ethanol on the dopaminergic system indirectly activate serotoninergic pathways as demonstrated by the observation that these effects can be attenuated by 5 -HT3 receptor antagonists. ${ }^{44}$ The relationship between ethanol and 5-HT3 receptors has also been demonstrated in studies focusing on the theory that low 5-HT levels in the brain are a risk factor for alcoholism. ${ }^{45}$ Some active ingredients of drugs, such as ondansetron, a 5-HT3 antagonist, are successful in reducing alcohol consumption. ${ }^{46-48}$ Buspirone, a partial 5-HT1A receptor agonist, also exerts a reducing effect on alcohol consumption. ${ }^{49}$ Taken together, these studies show that the function and localization of different types of serotonin receptors determine their role in the modulation of alcohol consumption. ${ }^{25}$

\section{Effects of alcohol on the endocannabinoid system}

Alcohol tolerance and addiction are associated with the endocannabinoid system. This system consists of cannabinoid receptors coupled to $G$ proteins and endogenous cannabinoids (arachidonyl ethanolamine and 2-arachidonyl glycerol). ${ }^{40,50-52}$ The best known receptors are CB1 and CB2. The CB1 receptor is widely distributed in the brain and is located in the presynaptic terminal. This receptor is responsible for the main psychoactive effects of cannabinoids. The $\mathrm{CB} 2$ receptor mainly mediates peripheral effects and its expression plays an important role in the immune system..$^{50} \mathrm{New}$ therapeutic agonists of this receptor have shown a great potential in the treatment of alcoholic liver diseases. ${ }^{53}$

The higher density of $\mathrm{CB} 1$ receptors in certain brain regions may explain the involvement of this neurotransmission system in the main effects of ethanol. The high concentration of this receptor in basal ganglia and in the cerebellum may be responsible for alcohol-induced motor incoordination. The presence of the $\mathrm{CB} 1$ receptor in the hippocampus and in different regions of the cerebral cortex may explain cognitive deficits and recent amnesia. ${ }^{50}$

This relationship occurs by the understanding of the relationship between endocannabinoids and ethanol, based on the observation of independent studies that the chronic administration of ethanol increased the concentrations of fatty acid esters in the brain. ${ }^{54,55}$ The latter are used for the production of arachidonyl ethanolamine, whose degradation was inhibited by ethanol through blockade of the microsomal transporter. ${ }^{56}$ Other studies demonstrated increased levels of the endocannabinoid 2-arachidonyl glycerol after chronic exposure to ethanol. ${ }^{57}$ With respect to the effects of alcohol on CB1 receptors, it is known that chronic ethanol consumption or administration reduces the expression of these receptors in different brain regions, ${ }^{58,59}$ in addition to compromising signal transduction by decreasing the affinity of this receptor for its $\mathrm{G}$ protein. ${ }^{60}$

\section{Effects of alcohol on voltage-dependent $\mathrm{Ca}^{2}$ channels}

Another central action of alcohol related to motor coordination is its effect on voltage-dependent $\mathrm{Ca}^{2}$ channels. These channels play an important role in cell depolarization and repolarization. In addition, they regulate a series of cellular activities, including the release of neurotransmitters. Alcohol mainly acts on L-type calcium channels, inhibiting the opening of these channels. The lower influx of positively charged ions into the cell renders it less excitable, in addition to inhibiting the release of neurotransmitters. A larger number of these channels are found in cerebellum. Therefore, the action of alcohol in this region may explain the motor incoordination such as unsteady gait, attention deficits, and impaired sleepwake regulation. ${ }^{29}$

\section{Effects of alcohol on GIRK channels}

Another important effect of alcohol on the nervous system involves the activation of a specific type of potassium (K) channel, called $G$ protein-coupled inwardly-rectifying $\mathrm{K}$ (GIRK) channels. However, the molecular mechanism underlying this activation is not fully understood. GIRK channels possess specific structures that permit binding to the alcohol molecule. These structures mediate the alcohol-induced activation of GIRK channels, but do not influence the inhibition of these channels. ${ }^{2}$ Since they are proteins present on the plasma membrane of nerve cells that form K-selective pores, a neuron frequently expresses multiple types of $\mathrm{K}$ channels, which exert different functions in cell signaling. Many ion channels, such as those mediated by neurotransmitters (e.g., serotonin), are sensitive to ethanol and other alcohols. It can, therefore, be speculated that the excitation of these channels is associated with increased alcohol consumption. ${ }^{61}$

\section{Effects of alcohol on neurosteroids}

Several neuroactive steroids exhibit rapid non-genomic activity in the CNS. These rapid mechanisms of action include the modulation of NMDA and $\mathrm{GABA}_{\mathrm{A}}$ receptor activity. Studies have shown that positive or negative allosteric modulators of the NMDA receptor complex bind 
to distinct sites on this receptor, which differ from the binding sites of glycine, dizocilpine (MK-801), Mg2 and spermine. Furthermore, pregnenolone sulfate and dehydroepiandrosterone sulfate, which are negative allosteric modulators of the $\mathrm{GABA}_{\mathrm{A}}$ receptor, act as non-competitive antagonists to reduce the activity of $\mathrm{GABA}_{\mathrm{A}}$ and glycine receptors, whereas androsterone, progesterone, allotetrahydrodeoxycorticosterone, allopregnanolone, pregnenolone and epipregnanolone act as positive allosteric modulators of this receptor. ${ }^{62}$

Recently, interactions of neurosteroids with the effects of ethanol have been demonstrated. Allopregnanolone was shown to decrease sleep latency and to increase the ethanol-induced sleeping time, whereas pregnenolone sulfate and dehydroepiandrosterone sulfate reduced sleep duration. In addition, an increase in blood allopregnanolone levels induced by ethanol was demonstrated in rats. With respect to the motor impairment caused by ethanol, dehydroepiandrosterone sulfate exerts a stimulatory effect, whereas an inhibitory effect is observed for allotetrahydrodeoxycorticosterone. ${ }^{62}$

In view of their multiple relationships with alcohol, these neuroactive steroids are studied for the treatment of alcoholism and may be useful for the development of drugs designed to minimize the effects caused by alcohol. ${ }^{62}$

Tables 1, 2 and 3 summarize the neuronal pathways that are stimulated and inhibited by alcohol, their respective neurotransmitters and/or signaling pathways, receptors, and the effects induced by the presence of alcohol in the CNS.

\section{Discussion AND CONCLUSION}

The results of this review show the multiple actions of alcohol on numerous central neurotransmission pathways, highlighting its role as a potent "dirty drug" and a CNS disorganizer. The results were organized in Tables 1 and 2, according to the pathways activated or inhibited by alcohol, respectively. This approach permitted to associate the classical biological actions of ethanol with the mo- lecular signaling pathways involved. Among the central actions stimulated by alcohol, its inhibitory gabaminergic effect, in conjunction with the inhibition of certain excitatory glutamatergic receptors, endocannabinoids, cerebellar calcium channels and hippocampal proteins (ERKs) which are essential for memory formation, results in sedation, loss of inhibitions, relaxation, loss of cognitive functions, attention deficit, impaired sleep-wake regulation (blackout effect), and the final state of psychomotor depression.

On the other hand, the excitatory action of alcohol on mu receptors of the opioid system and subsequent activation of the limbic system by dopamine and of 5-HT1B receptors by serotonin result in the effect of well-being and mood elevation. In addition, the down-regulation of dopamine and GABA receptors explains the increase in alcohol consumption and subsequent development of chemical dependency.

Finally, a better understanding of the effect of 5-HT3 antagonists that are able to reduce alcohol consumption, as well as of neurosteroids modulating gabaminergic receptors, should lead to the identification of new therapeutic perspectives. However, since dealing with the subject exhaustively was not the objective of this review, and since many of the studies cited are very recent, it is likely that interactions of alcohol with other neuronal pathways, as well as their interrelations, will be described in the future.

\section{Resumo}

Uma revisão sobre o álcool: do mecanismo de ação central à dependência química

Introdução: o álcool é uma substância psicotrópica depressora do sistema nervoso central (SNC), que promove alteração simultânea de inúmeras vias neuronais, gerando profundo impacto neurológico e traduzindo-se em diversas alterações biológicas e comportamentais.

TABLE 1 Neurotransmission pathways stimulated by alcohol, their respective neurotransmitter and receptor, and biological response induced in the central nervous system.

\begin{tabular}{|c|c|c|}
\hline $\begin{array}{l}\text { Neurotransmission pathway } \\
\text { (neurotransmitter) }\end{array}$ & Receptor & Biological effect \\
\hline Gabaminergic (GABA) & $\begin{array}{l}\text { Ionotropic: } \mathrm{GABA}_{\mathrm{a}} \text { and } \mathrm{GABA}_{c}{ }^{4,35,37-39} \\
\text { Metabotropic: } \mathrm{GABA}_{c}\end{array}$ & $\begin{array}{l}\text { Inhibition of CNS, manifesting as sedation, loss of } \\
\text { inhibitions, and relaxation } n^{4,34,36}\end{array}$ \\
\hline Opioid (dopamine) & $\mathrm{Mu}^{16,18-22}$ & Pleasure, satisfaction, increased search for alcohol ${ }^{19,22}$ \\
\hline Serotoninergic & $5-\mathrm{HT} 3^{48,49,56}$ & Feeling of well-being and mood elevation ${ }^{12,23,24,48,50}$ \\
\hline
\end{tabular}


TABLE 2 Neurotransmission pathways inhibited by alcohol, their respective neurotransmitter and receptor, and biological

response induced in the central nervous system.

\begin{tabular}{|c|c|c|}
\hline $\begin{array}{l}\text { Neurotransmission pathway } \\
\text { (neurotransmitter) }\end{array}$ & Receptor & Biological effect \\
\hline Glutamatergic (glutamate) & $\begin{array}{l}\text { Ionotropic: AMPA, kainate or } \mathrm{NMDA}^{29} \\
\text { Metabotropic: } \mathrm{rM1}, \mathrm{rM}^{29}\end{array}$ & $\begin{array}{l}\text { Reduced cognitive functions, attention deficit, and } \\
\text { impaired sleep-wake regulation; blackout } \\
\text { phenomenon }{ }^{21,29,40,41}\end{array}$ \\
\hline Opioid (dopamine) & Delta $^{16,22}$ & Reduced search for alcohol ${ }^{19,22}$ \\
\hline Endocannabinoid (AEA, 2-AG) & $\mathrm{CB} 1, \mathrm{CB} 2^{26,27}$ & Motor incoordination, difficulty in logical reasoning ${ }^{25}$ \\
\hline MAPK & $\mathrm{ERKs}^{13}$ & Loss of explicit memory ${ }^{8,13}$ \\
\hline Calcium channels & L-type in the cerebellum ${ }^{22}$ & Unsteady gait and loss of spatial notion ${ }^{22}$ \\
\hline GIRK channels & Potassium channels ${ }^{2,3}$ & Altered neurotransmission ${ }^{2,3}$ \\
\hline
\end{tabular}

AEA: arachidonyl ethanolamine; 2-AG: 2-arachidonyl glycerol.

TABLE 3 Action of neurosteroids in the effects caused by ethanol.

\begin{tabular}{lll} 
Neurosteroid & Action & Biological effect \\
\hline Allopregnanolone & Positive allosteric modulator of $\mathrm{GABA}_{\mathrm{A}}{ }^{62}$ & Reduction in sleep latency and in sleeping time $^{62}$ \\
\hline Pregnenolone sulfate & Negative allosteric modulator of $\mathrm{GABA}_{\mathrm{A}}{ }^{62}$ & Reduction in sleep duration $^{62}$ \\
\hline Dehydroepiandrosterone sulfate & Negative allosteric modulator of $\mathrm{GABA}_{\mathrm{A}}{ }^{62}$ & Reduction in sleep duration and motor stimulus $^{62}$ \\
\hline Allotetrahydrodeoxycorticosterone & Positive allosteric modulator $\mathrm{GABA}_{\mathrm{A}}{ }^{62}$ & Motor inhibition $^{62}$ \\
\hline
\end{tabular}

Objetivos: descrever as ações do álcool sobre o SNC, identificando as vias de sinalização modificadas e os efeitos biológicos gerados pelo seu consumo.

Métodos: revisão bibliográfica, priorizando trabalhos multilinguísticos publicados nos últimos 15 anos.

Resultados: são descritas ação direta do álcool em inúmeros receptores de neurotransmissores (ácido gama-aminobutírico - GABA, glutamato, endocanabinoides AEA e 2-AG, entre outros), ação indireta do álcool no sistema límbico e opioide, ação sobre canais de cálcio, potássio e proteínas reguladas por GABA no hipocampo, além de ações centrais mediadas pela deficiência de vitamina B1.

Conclusão: a ação multifocal do álcool sobre o SNC resulta em efeito geral de depressão psicomotora, dificuldades no armazenamento de informações e no raciocínio lógico, incoordenação motora, além da estimulação do sistema de recompensa, o que pode explicar o desenvolvimento da dependência química. O conhecimento das vias de sinalização neuronais alteradas pelo álcool permite reconhecer a descrição de efetores que possam reduzir sua ação central e, assim, vislumbrar novas perspectivas terapêuticas para a reabilitação de adictos a essa substância.

Palavras-chave: transtornos do sistema nervoso induzidos por álcool, neurotransmissores, receptores de neurotransmissores.

\section{References}

1. Maher JJ. Exploring alcohol effects on liver function. Alcohol Health Res World. 1997; 21(1):5-12.

2. Heckmann W, Silveira CM. Dependência do álcool: aspectos clínicos e diagnósticos. In: Andrade AG, Anthony JC (eds.). O álcool e suas consequências, uma abordagem multiconcenitual. Barueri: Minha Editora, 2009. p.67-87.

3. Haes TM. Álcool e sistema nervoso central. Rev Fac Med Rib Preto. 2010; 43(2):153-63.

4. Álcool. In: Diehl A, Cordeiro DC, Laranjeira R (eds.). Dependência química: prevenção tratamento e políticas públicas. 1.ed. Porto Alegre: Artmed, 2011. p.129-44.

5. Charlton ME, Sweetnan PM, Fitzgerald LW, Terwilliger RZ, Nestler EJ, Duman RS. Chronic ethanol administration regulates the expression of GABAA, receptor $\alpha 1$ and $\alpha 5$ subunit in the ventral tegmental area and hippocampus. J Neurochem. 2002; 68(1):121-7.

6. Lüddens H, Seeburg PH, Korpi ER. Impact of beta and gamma variants on ligand-binding properties of gamma-aminobutyric acid type A receptors. Mol Pharmacol. 1994; 45(5):810-4.

7. Smith GB, Olsen RW. Functional domains of GABAA receptors. Trends Pharmacol Sci. 1995; 16(5):162-8

8. Gruol DL, Netzeband JG, Parsons KL. Calcium signals pathways linked to glutamate recptor activation in the somatic and dendritic regions of cultured cerebellar purkinje neurons. J. Neuropysiol. 1996; 76(5):3325-40.

9. Berman MO, Shagrin B, Evert DL, Epstein C. Impairments of brain and behavior: the neurological effects of alcohol. Alcohol Health Res World. 1997; 21(1):65-75.

10. Sieghart W. Structure and pharmacology of g-aminobutyric acid receptor subtypes. Pharmacol Rev. 1995; 47(2):181-234.

11. Mohler H, Fritschy JM, Benke D, Benson J, Rudolph U, Lüscher B. GABAA receptor subtypes: pharmacological significance and mutation analyses in vivo. In: Tanaka C, Bowery NG (eds.). GABA: receptors, transporters and metabolism. Boston: Advances in pharmacological sciences, 1996. p.157-71.

12. Lovinger DM. Excitotoxicity and alcohol-related brain damage. Alcohol Clin Exp Res. 1993; 17(1):19-27.

13. Beresford TP, Arciniegas DB, Alfers J, Clapp L, Martin B, Liu YDD, et al. Hippocampus volume loss due to chronic heavy drinking. Alcohol Clin Exp Res. 2006; 30(11):1866-70. 
14. Zheng G, Zhang W, Zhang Y, Chen Y, Liu M, Yao T, et. al. Gamma-aminobutyric acid(A) $(\mathrm{GABA}(\mathrm{A}))$ receptor regulates ERK1/2 phosphorylation in rat hippocampus in high doses of methyl tert-butyl ether (MTBE)-induced impairment of spatial memory. Toxicol Appl Pharmacol. 2009; 236(2):239-45

15. Lombroso P. Aprendizado e memória. Rev Bras Psiquiatr. 2004; 26(3):207-10.

16. Young C, Straiko MM, Johnson SA, Creeley C, Olney JW. Ethanol causes and lithium prevents neuroapoptosis and suppression of perk in the infant mouse brain. Neurobiol Dis. 2008; 31(3):355-60.

17. Grant BF, Dufour MC, Harford TC. Epidemiology of alcoholic liver disease. Seminars Liver Dis. 1998; 8(1):12-25.

18. Gruol DL, Parsons KL, DiJulio N. Acute ethanol alters calcium signals elicited by glutamate receptor agonists and $\mathrm{K}$ depolarization in cultured cerebellar Purkinje neurons. Brain Res. 1997; 773(1):82-9.

19. Castro LA, Baltieri DA. Tratamento farmacológico da dependência do álcool. Rev Bras Psiq. 2004; 26(supl.):43-6

20. Mayer M, Westbrook G. Permeation and block of NMDA receptor channels by divalent cations in mouse cultured central neurons. J Physiol. 1987; 394(1):501-27.

21. Hartley DM, Kurth MC, Bjerkness L, Weiss JH, Choi DW. Glutamate receptorinduced 45Ca2+ accumulation in cortical cell culture correlates with subsequent neuronal degeneration. J Neurosci. 1993; 13(5):1993-2000.

22. Tymian M, Charlton MP, Carlen PL, Tator, CH. Source specificity of early calcium neurotoxicity in cultured embryonic spinal neurons. J Neurosci. 1993; 13(5):2085-104.

23. Clapp P, Bhave SJ, Hoffman PL. How adaptation of the brain to alcohol leads to dependence: a pharmacological perspective. Alcohol Res Health. 2008; 31(4):310-39.

24. Chang-Mu C, Jen-Kun L, Shing-Hwa L, Shoei-Yn LS. Characterization of neurotoxic effects of NMDA and the novel neuroprotection by phytopolyphenols in mice. Behav Neurosci. 2010; 124(4):541-53.

25. Bittencourt AL. Mecanismo de ação do etanol: envolvimento de etanol, gaba e dopamina. Rev Psiq Clin. 2000; 27(1):26-31.

26. Aminoff MJ. Neurology and General Medicine. 4.ed. Churchill Living, 2007.

27. Gilpin NW, Koob GF. Neurobiology of alcohol dependence: focus on motivational mechanisms. Alcohol Res. Health. 2008; 31(3):185-95.

28. World Health Organization. Neuroscience of Psychoactive Substance Use and Dependence. 1.ed. Geneva: WHO Library Catouloguing-in-Publication Data, 2004. Chapter 1-2. p.1-40.

29. Zaleski M, Morato GS, Silva VA, Lemos T. Aspectos neurofarmacológicos do uso crônico e da síndrome de abstinência do álcool. Rev Bras Psiquiatr. 2004; 26(1):40-2.

30. Martins HS, Neto As, Velasco IT. Emergências Clínicas Baseadas em Evidências. Disciplina de Emergências Clínicas do Hospital das Clínicas da Faculdade de Medicina de São Paulo. São Paulo: Atheneu, 2005.

31. Pradhan AA, Befort K, Nozaki K, Ruff CG, Kieffer BL. The delta opioid receptor: an evolving target for the treatment of brain disorders. Trends Pharmacol Sci. 2011; 32(10):581-90.

32. Lovinger DM. O papel da serotonina anos efeitos do álcool sobre o cérebro. Alcohol Health Res World. 1997; 21(2):114-20.

33. Vengelien V, Bilbao A, Molander A, Spanagel R. Neuropharmacology of alcohol addiction. Br. J Pharmacol. 2008; 154(2):299-15.

34. Boullosa O, Lopez-Mato AM. Recent advances in the serotonin neurotransmitters configuration. Psiquiatr Biol. 1995; 3(3):37-51.

35. Laranjeira R, Nicastri S, Jerônimo C, Marques AC. Consenso sobre a síndrome de abstinência do álcool (SAA) e o seu tratamento. Rev Bras Psiquiatr. 2000; 22(2):62-71.

36. Lee R, Petty, F, Coccaro, EF. Cerebrospinal fluid GABA concentration: Relationship with impulsivity and history of suicidal behavior, but not aggression, in human subjects. J. Psychiatry Res. 2008; 43(4):353-9.

37. Hoyer D, Hannon JP, Martin GR. Molecular, pharmacological and functional diversity of 5-HT receptors. Pharmacol Biochem Behav. 2002; 71(4):533-54.

38. Sartania N, Strange PG. Role of conserved serine residues in the interaction of agonists with D3 dopamine receptors. J Neurochem. 2002; 72(6):2621-4.

39. Tomkins DM, Joharchi N, Tampakeras M, Martin JR, Wichmann J, Higgins GA. An investigation of the role of 5-HT2C receptors in modifying ethanol selfadministration behaviour. Pharmacol Biochem Behav. 2002; 71(4):735-44 .
40. Blednov IA, Cravatt BF, Boehm SL, Walker D, Harris RA. Role of endocannabinoids in alcohol consumption and intoxication: studies of mice lacking fatty acid amide hydrolase. Neuropsychopharmacol. 2007; 32(7):1570-82.

41. Hoplight BJ, Sandygren NA, Neumaier JF. Increased expression of 5-HT1B receptors in rat nucleus accumbens via virally mediated gene transfer increases voluntary alcohol consumption. Alcohol. 2006; 38(2):73-9.

42. Risinger FO, Doan AM, Vickery AC. Oral operant ethanol self-administration in 5-HT1b knockout mice. Behav Brain Res. 1999; 102(1-2):211-5.

43. Hodge CW, Kelley SP, Bratt AM, Iller K, Schroeder JP, Besheer J. 5-HT(3A) receptor subunit is required for 5-HT3 antagonist-induced reductions in alcohol drinking. Neuropsychopharmacol. 2004; 29(10):1807-13.

44. Carboni A, Frau R, Di Chiara G. Differential inhibitory effects of a 5-HT3 antagonist on drug-induced stimulation of dopamine release. Eur J Pharmacol. 1989; 164(3):515-9.

45. Lovinger DM. Ethanol potentiation of $5 \mathrm{HT} 3$ receptor-mediated ion current in NCB-20 neuroblastoma cells. Neurosci Lett. 1991; 122(1):57-60.

46. Ait-Daoud N, Johnoson BA, Prihioda TJ, Hargita ID. Combining ondansetron and naltrexone reduces craving among biologically predisposed alcoholics: preliminary clinical evidence. Psychopharmacol (Berl). 2001; 154(1):23-7.

47. Johnson BA, Roache JD, Javors MA, Diclemente CC, Cloninger CR, Prihoda TJ, Bordnick PS, Ait-Daoud N, Hensler J. Ondansetron for reduction of drinking among biologically predisposed alcoholic patients: a randomized controlled trial. JAMA. 2000; 284(8):963-71.

48. Kranzler HR, Pierucci-Lagha A, Feinn R, Hernandez-Avila C . Effects of ondansetron in early-versus late-onset alcoholics: a prospective, open-label study. Alcohol Clin Exp Res. 2003; 27(7):1150-5.

49. Kranzler HR, Burleson JA, Del Boca FK, Babor TF, Korner P, Brown J, Bohn MJ. Buspirone treatment of anxious alcoholics. Arch Gen Psychiatry. 1994; 51(9):720-31.

50. Cocaína e crack. In: Diehl A, Cordeiro DC, Laranjeira R, Lacerda ALT, Junior AR, Bonadio AN, et al. (eds.). Dependência química. 1.ed. Porto Alegre: Artmed, 2011. p.170-9.

51. Maconha. In: Diehl A, Cordeiro DC, Laranjeira R, Lacerda ALT, Junior AR, Bonadio AN, et al. (eds.). Dependência química. 1.ed. Porto Alegre: Artmed, 2011. p.161-9.

52. Tabakoff B, Hoffman PL. Neurochemical correlates of ethanol withdrawal: alterations in serotonergic function. J Pharm Pharmacol. 1977; 29(8):471-6.

53. Louvet A, Teixeira-Clerc F, Chobert MN, Deveaux V, Pavoine C, Zimmer A, et al. Cannabinoid CB2 receptors protect against alcoholic liver desease by regulating kupffer cell polarization in mice. Hepatology. 2011; 54(4):1217-26.

54. Hungund BL, Goldstein DB, Villegas F, Cooper TB. Formation of fatty acid ethyl esters during chronic ethanol treatment in mice. Biochem Pharmacol. 1988; 37(15):3001-4.

55. Laposata EA, Lange LG. Presence of nonoxidative ethanol metabolism in human organs commonly damaged by ethanol abuse. Science. 1986; 231(4737):497-9.

56. Basavarajappa BS, Saito M, Cooper TB, Hungund BL. Chronic ethanol inhibits the anandamide transport and increases extracellular anandamide levels in cerebellar granule neurons. Eur J Pharmacol. 2003; 466(1-2):73-83.

57. Basavarajappa BS, Saito M, Cooper TB, Hungund BL. Stimulation of cannabinoid receptor agonist 2-arachidonylglycerol by chronic ethanol and its modulation by specific neuromodulators in cerebellar granule neurons. Biochem Biophys Acta. 2000; 1535(1):78-86

58. Basavarajappa BS, Saito M, Cooper TB, Hungund BL. Chronic ethanol administration down-regulates cannabinoid receptors in mouse brain synaptic plasma membrane. Brain Res. 1998; 793(1-2):212-8.

59. Ortiz S, Oliva JM, Perez-Rial S, Palomo T, Manzanares J. Chronic ethanol consumption regulates cannabinoid CB1 receptor gene expression in selected regions of rat brain. Alcohol. 2004; 39(2):88-92.

60. Basavarajappa BS, Hungund, BL. Down-regulation of cannabinoid receptor agonist-stimulated [35S]GTP gamma S binding in synaptic plasma membrane from chronic ethanol exposed mouse. Brain Res. 1999; 815(1):89-97.

61. Prafulla A, Hay D, Senyon C, Paul A, Slesinger AS. A discrete alcohol pocket involved in GIRK channel activation. Nat Neurosci. 2009; 12(1):988-95.

62. Barbosa ADE, Morato GS. Influência da epipregnanolona sobre a modulação da tolerância rápida ao etanol pelos neuroesteróides. Rev Bras Psiquiatr. 2007; 29(4):337-45 